\title{
Combined Magnesia, Ceria and Nickel catalyst supported over $\gamma$-Alumina Doped with Titania for Dry Reforming of Methane
}

\author{
Ahmed Sadeq Al-Fatesh 1,*, Samsudeen Olajide Kasim ${ }^{1}$, Ahmed Aidid Ibrahim ${ }^{1}$, Anis Hamza \\ Fakeeha 1, Ahmed Elhag Abasaeed 1, Rasheed Arasheed 2, Rawan Ashamari ${ }^{2}$, \\ Abdulaziz Bagabas 2,* \\ 1 Chemical Engineering Department, College of Engineering, King Saud University, P.O. Box 800, \\ Riyadh 11421, Saudi Arabia; aalfatesh@ksu.edu.sa (A.S.A.-F.); sofkolajide2@gmail.com (S.O.K.); \\ aidid@ksu.edu.sa (A.A.I.); anishf@ksu.edu.sa (A.H.F.); abasaeed@ksu.edu.sa (A.E.A) \\ 2 National Petrochemical Technology Center (NPTC), Materials Science Research Institute (MSRI), King \\ Abdulaziz City for Science and Technology, P.O. Box 6086, Riyadh 11442, Saudi Arabia; \\ rrisheed@kacst.edu.sa (R.Ar.); ralshammary@kacst.edu.sa (R. As.); abagabas@hotmail.com (A.B.) \\ * Correspondence: aalfatesh@ksu.edu.sa (A.S.A.-F), abagabas@hotmail.com (A.B); Tel.: +966-11-467-6859, \\ +966-11-481-3790
}

\begin{abstract}
This study investigated dry reforming of methane with combined catalysts supported on $\gamma-\mathrm{Al}_{2} \mathrm{O}_{3}$ support doped with $3.0 \mathrm{wt}$. \% $\mathrm{TiO}_{2}$. The physicochemical properties of all the catalysts were determined by inductively-coupled plasma/mass spectrometry metal analysis, nitrogen physisorption, X-ray diffraction, temperature programmed reduction/desorption, thermogravimetric analysis, and scanning electron microscopy. The addition of $\mathrm{CeO}_{2}$ and $\mathrm{MgO}$ to $\mathrm{Ni}$ strengthened the interaction between the $\mathrm{Ni}$ and the support. The catalytic activity results indicated that the $\mathrm{CeO}_{2}$ and $\mathrm{MgO}$ addition to $\mathrm{Ni}$ did not do much in retarding carbon deposition, but they improved the activity of the catalysts. Among the tested catalysts, it was found that the catalyst with the composition of $5.0 \mathrm{wt} \% \mathrm{NiO}-10.0 \mathrm{wt} \% \mathrm{CeO}_{2} / 3.0 \mathrm{wt} \% \mathrm{TiO}_{2}-\gamma-\mathrm{Al}_{2} \mathrm{O}_{3}$ resulted in the highest $\mathrm{CH}_{4}$ and $\mathrm{CO}_{2}$ conversion with $\mathrm{H}_{2} / \mathrm{CO}$ mole ratio close to unity. The optimum reaction conditions in terms of reactant conversion and $\mathrm{H}_{2} / \mathrm{CO}$ mole ratio were achieved by varying space velocity and $\mathrm{CO}_{2} / \mathrm{CH}_{4}$ mole ratio.
\end{abstract}

Keywords: $\mathrm{CH}_{4}, \mathrm{CeO}_{2}$, Dry reforming, $\mathrm{MgO}, \mathrm{Ni}, \mathrm{TiO}_{2}$

\section{Introduction}

The global warming has become an alarming issue. The emissions of greenhouse gases of carbon dioxide and methane $\left(\mathrm{CO}_{2}\right.$ and $\left.\mathrm{CH}_{4}\right)$ contribute actively to this problem. Methods of transforming these two gases into useful products are worth from the prospect of the environmental safety and the economic point of view of generating value-added fuels and chemicals [1-3]. In this context, numerous reforming reactions of $\mathrm{CH}_{4}$ have been employed using several oxidants such $\mathrm{H}_{2} \mathrm{O}, \mathrm{CO}_{2}$ and $\mathrm{O}_{2}$ for the production of hydrogen or synthesis gas (syngas; hydrogen and carbon monoxide mixture) with a $\mathrm{H}_{2}: \mathrm{CO}$ molar ratio of one through processes such as steam reforming of methane, auto thermal reforming, tri-reforming of methane, etc. [7-11]. The $\mathrm{CO}_{2}$ reforming of methane process, known as dry reforming of $\mathrm{CH}_{4}(\mathrm{DRM})$, has attracted the 
investigators because it mitigates the emission of $\mathrm{CH}_{4}$ and $\mathrm{CO}_{2}$, transforms them into synthesis gas, the starting material in the Fischer-Tropsch process to generate hydrocarbons and oxygenates, and generates clean energy through the combustion of hydrogen [12]. $\mathrm{CH}_{4}$ is the chief component of natural gas and biogas with the total composition of $80-90 \%$. Therefore, it is cost-effective feedstock for syngas production. The primary reaction that governs the process is as follows:

$$
\mathrm{CH}_{4}+\mathrm{CO}_{2} \rightarrow 2 \mathrm{H}_{2}+2 \mathrm{CO} \quad \Delta \mathrm{H}_{298}=+247 \mathrm{kJmol}^{-1}
$$

The reaction is immensely endothermic and needs to be operated at high temperature for the achievement of acceptable conversions. The active elements in the catalyst of the $\mathrm{CO}_{2}$ reforming of methane include both noble metals such as $\mathrm{Ru}, \mathrm{Rh}$, or $\mathrm{Pt}$, and first row transition metals like $\mathrm{Ni}$, $\mathrm{Fe}$, and Co. Although noble metals display high activity and stability, their limited availability and high price have made them inappropriate for industrial use $[13,14]$. On the other hand, the first row transition metals are cheaper and possess similar activity, but their stability is hampered by carbon deposition and particle sintering [15-18]. Therefore, the development of Ni-based catalysts with high activity and resistance to the deactivation due to the carbon formations and metal sintering is essential for DRM. Many efforts have been carried out to develop catalysts that possess high activity and stability. The catalytic performance can be influenced by many factors such as the active metal and support type and texture. The support enhances the catalyst selectivity, activity and stability by increasing the surface area and the active metal dispersion [19]. Alumina support has high specific surface area and promotes active metal dispersion on its surface which results in high catalytic activity. But, Ni deactivates fast due to sintering, coke deposition, and formation of surface nickel aluminate phase that influences the entire dynamics of $\mathrm{CO}_{2}$ reforming process. To increase the catalytic performance of nickel $/ \gamma$-alumina, various parameters can be incorporated in the catalyst.

Pure Titania $\left(\mathrm{TiO}_{2}\right)$ is characterized by low specific surface area, poor mechanical strength, and phase transformation (anatase to rutile) at high temperatures, and thus, it does not suit for high temperature reactions [20]. Previous studies exhibited that introducing thermally stable second metal oxide like silica $\left(\mathrm{SiO}_{2}\right)$ can stabilize the degradation of the textural properties of the $\mathrm{TiO}_{2}$ and can be employed as support [21, 22]. Incorporation of $\mathrm{TiO}_{2}$ in the alumina support improves the dispersion of metal on the support, lowers the sintering, upgrades the stability to heat, in addition, enhances the capacity to store oxygen which assists in gasifying the carbon that was produced in the course of the reforming reaction [23]. Tauster et al investigated the effects of modification of the support on the oxidation state of ruthenium $(\mathrm{Ru})$ and the catalytic performance of $\mathrm{Ru} / \mathrm{TiO}_{2}$ catalysts under conditions of partial oxidation of methane to synthesis gas. It was found that doping of $\mathrm{TiO}_{2}$ with small amounts of $\mathrm{W}^{6+}$ cations favored oxygen adsorption on $\mathrm{Ru}$ under reaction conditions, and thus, it resulted in stabilization of a fraction of the catalyst in its oxidized forms [25]. On the other hand, the active Ni metal component has been improved by the addition of metal oxide promoters. For instance, Shamskar et al. investigated the addition of ceria $\left(\mathrm{CeO}_{2}\right)$, lanthana $\left(\mathrm{La}_{2} \mathrm{O}_{3}\right)$, and zirconia $\left(\mathrm{ZrO}_{2}\right)$ to $\mathrm{Ni} / \mathrm{Al}_{2} \mathrm{O}_{3}$ catalyst used for DRM and found that ceriapromoted catalyst reduced the carbon formation [25]. Ni-MgO- $\mathrm{Al}_{2} \mathrm{O}_{3}$ catalysts were used for steam reforming of methane by Jang et al. [26]. Al-Fatesh et al studied the promotional effect of ceria in the catalytic DRM and found that the Ni doping with ceria resulted in an excellent activity and less coke formation [27]. The magnesia $(\mathrm{MgO})$ promoter enhanced the $\mathrm{CH}_{4}$ conversion and mitigated the effect of the potassium poisoning of the Ni-based catalyst. The $\mathrm{MgO}$ promoter is beneficial in suppressing carbon formation.

In the present work, supported combination of $\mathrm{Mg}$, $\mathrm{Ce}$ and $\mathrm{Ni}$ catalysts have been developed to retain high activity and stability while reducing the formation of coke during the DRM. The 
effect of using $\mathrm{MgO}$ and $\mathrm{CeO}_{2}$ as separate and combined promoters, for $5.0 \mathrm{wt} \% \mathrm{NiO}$ supported over $\gamma-\mathrm{Al}_{2} \mathrm{O}_{3}$ doped with 3.0 wt $\% \mathrm{TiO}_{2}$ was studied. Different techniques were employed to characterize the various prepared catalyst systems to perceive the observed catalytic performance and the impact of each modifier.

\section{Results and Discussion}

\subsection{Structure and Morphology}

The XRD patterns of all the fresh catalysts are displayed in Figure 1. All the patterns consisted of various metal oxides, where the presence metal oxide phases depended on the added components used to prepare the catalysts. Three metal oxides existed in all catalysts, where these metal oxides were the component of the support: cubic gamma-aluminum oxide, $\gamma-\left(\mathrm{Al}_{2} \mathrm{O}_{3}\right)_{1.333}$ (PDF 01-075-0921), cubic synthesized honguiite titanium oxide, ( $\left.\mathrm{TiO}_{0.8}\right)_{0.913}$ (PDF 01085-1380), and aluminum silicate, $\mathrm{Al}_{0.5} \mathrm{Si}_{0.75} \mathrm{O}_{2.25}$ (PDF 00-037-1460). On the other hand, rhombohedral nickel oxide, NiO (PDF 00-044-1159) was found in Ti-CAT-I, Ti-CAT-II, Ti-CATIII, and Ti-CAT-V. However, when magnesium was added, cubic magnesium nickel oxide, $\mathrm{MgNiO}_{2}$ (PDF 00-024-0712) formed. Cubic synthesized cerianite (Ce) (ceria), $\mathrm{CeO}_{2}$ (PDF 00-0340394), was detected in Ti-CAT-I, Ti-CAT-II, Ti-CAT-IV, and Ti-CAT-VI. Addition of magnesium influenced strongly the interaction of cerium with the other components of the catalyst, where monoclinic magnesium cerium oxide, $\mathrm{MgCeO}_{3}$ (PDF 00-004-0641), and cubic magnesium cerium titanium oxide, $\mathrm{Mg}_{2} \mathrm{CeTiO}_{6}$ (PDF 00-058-0550) existed in Ti-CAT-I and Ti-CAT-IV. Cubic periclase magnesium oxide, MgO (PDF 01-071-1176) was detected in Ti-CAT-I, Ti-CAT-III, and Ti-CAT-IV. Therefore, XRD was a powerful technique to explore how each catalyst component affect other component through the formation of mixed metal oxides.

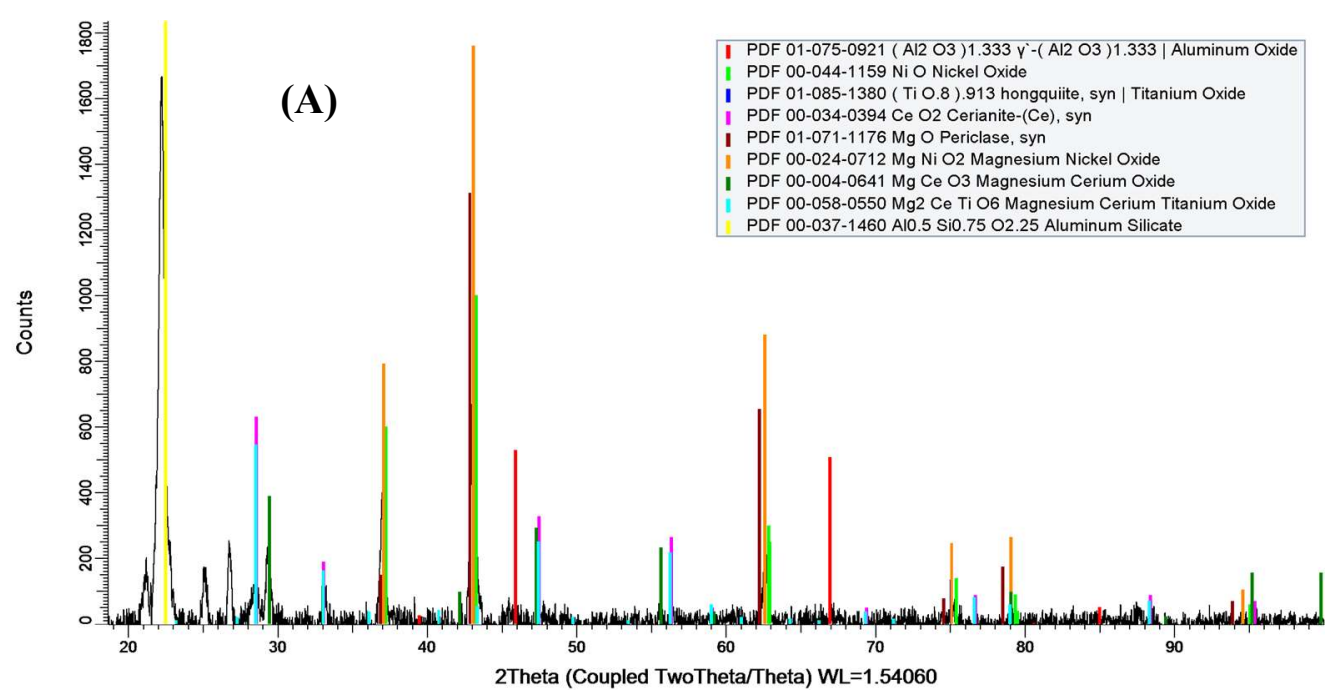



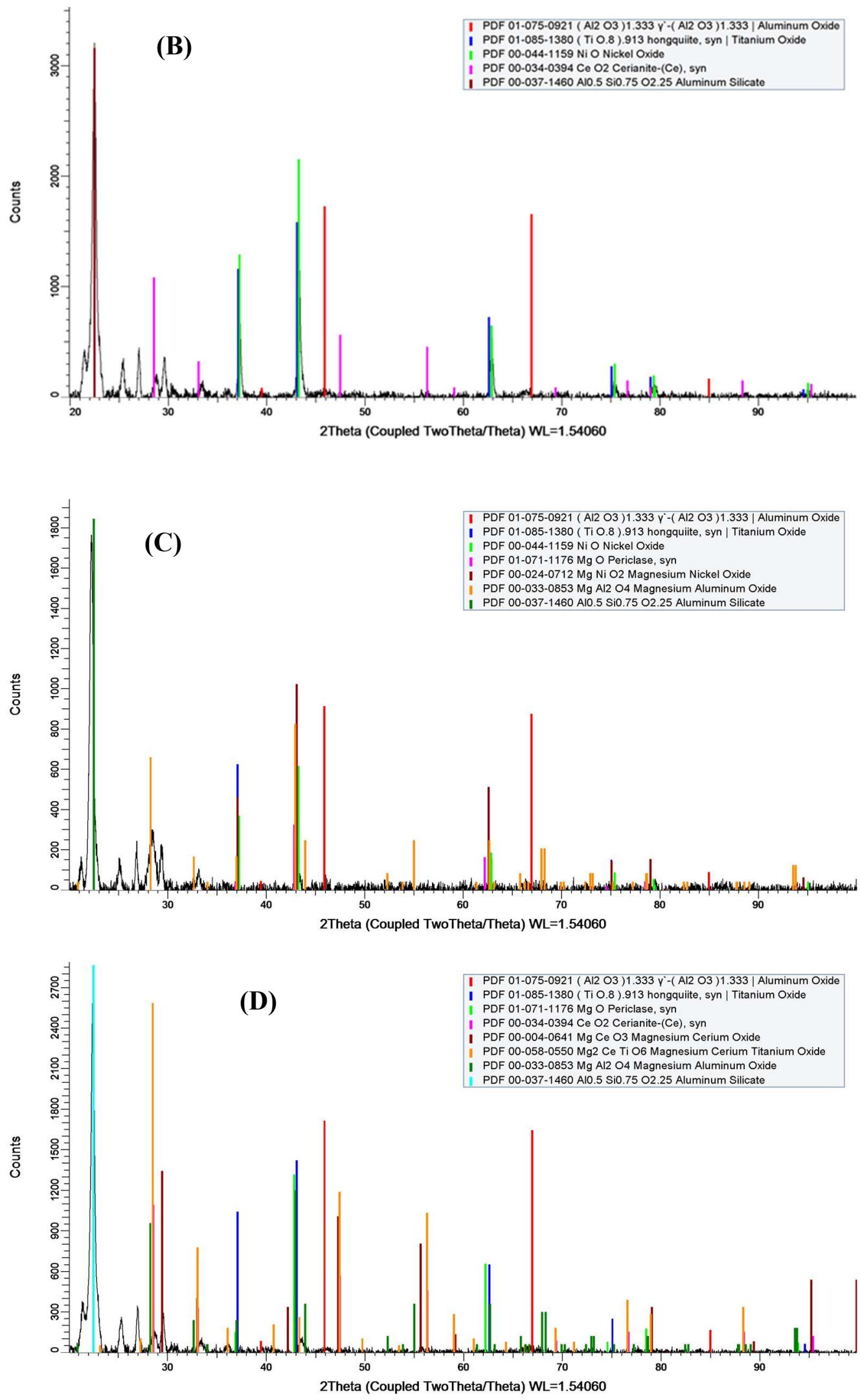

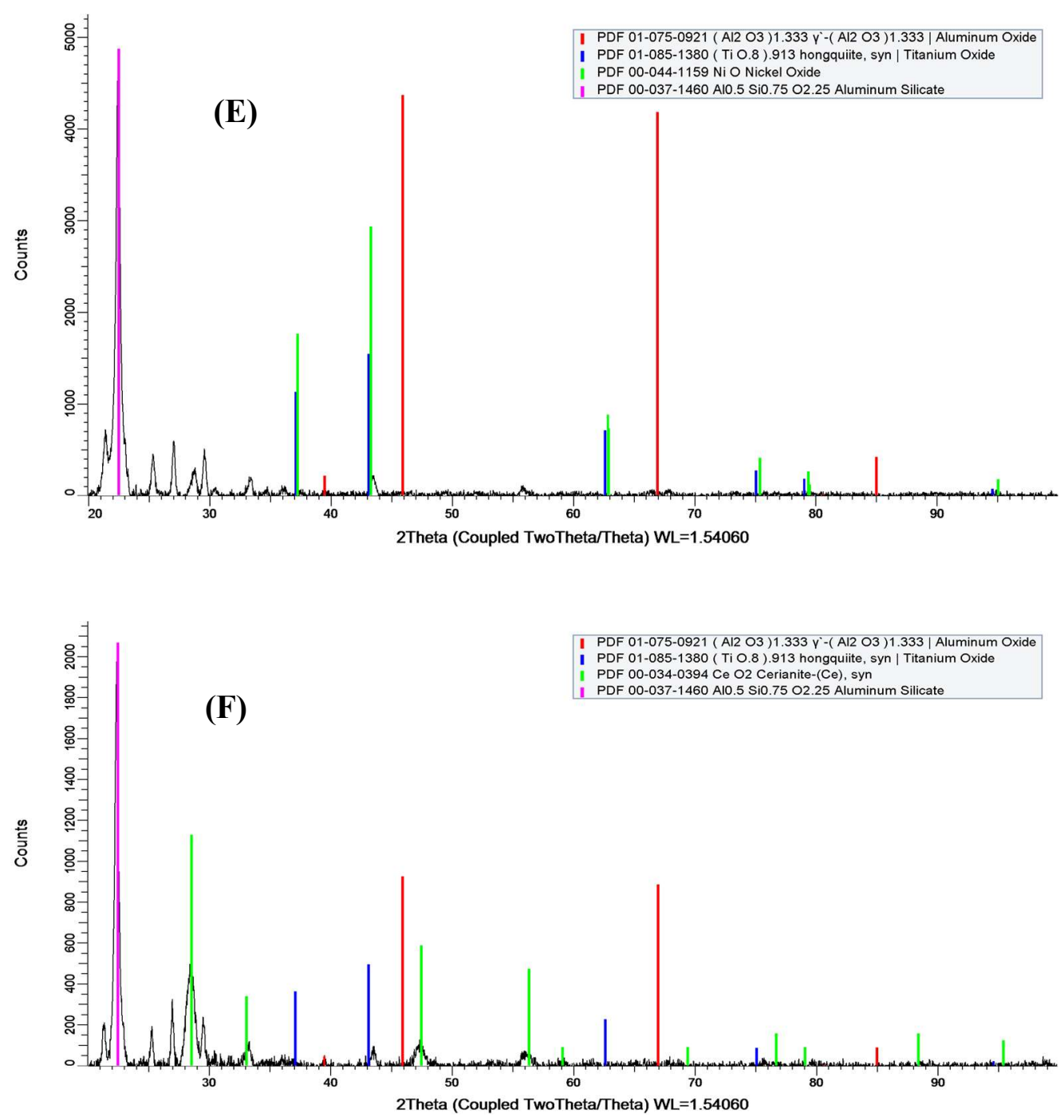

Figure 1. XRD patterns of fresh catalysts: (A) Ti-CAT-I, (B) Ti-CAT-II, (C) Ti-CAT-III, (D) Ti-CAT-IV, (E) TiCAT-V, and (F) Ti-CAT-VI.

Both fresh and spent catalysts had their morphology explored by SEM technique. Figure 2 shows the SEM micrographs for the best two catalysts: Ti-CAT-I and Ti-CAT-II. Similar morphology, based on agglomerated, spherical nanoparticles, was detected for both fresh catalysts [Figure 2 (A) and (B)]. Such observation was expected because both catalysts were synthesized by identical preparation procedure and had similar component with the exception that Ti-CAT-II had no magnesium in its matrix.

The morphology of the spent catalysts was similar to that one of the fresh samples except the presence of carbon nanotubes (CNTs) on the surface of the spent catalysts [Figure 2 (C) and (D)]. Detection of CNTs on the surface of the spent catalyst confirms the results of TGA of spent catalysts. The presence of CNTs on the surface of the spent catalysts could be attributed to Boudouard reaction, which in turn, would be responsible for reducing the catalytic performance. 


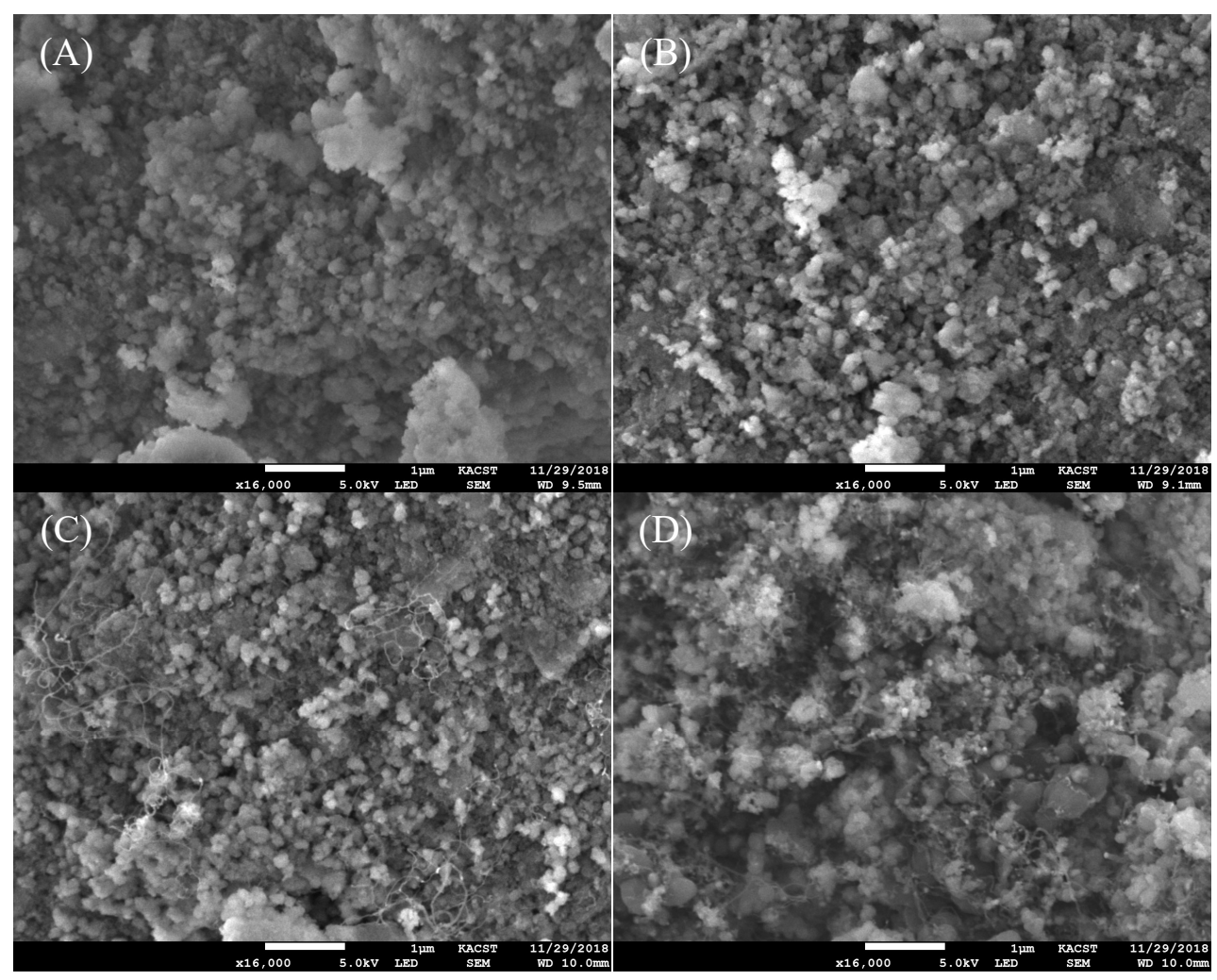

Figure 2. SEM micrographs for fresh catalysts (A) Ti-CAT-I, (B) Ti-CAT-II, and spent catalysts (C) Ti-CAT-I, (D) Ti-CAT-II.

\subsection{Inductively Coupled Plasma Mass Spectroscopy (ICP-MS)}

ICP-MS analysis was carried out to quantify the metallic components as metal oxides for the best two catalysts. The results are shown in the two tables below.

Table 1 summarizes the results of ICP analysis of the metallic components in the prepared catalysts and compares it with the theoretical values. The experimental results were found to be in excellent agreement with the nominal values. Therefore, ICP analysis confirmed the success of our preparation procedure for our targeted catalysts. 
Table 1a. ICP metal oxide microanalysis of Ti-CAT-I.

\begin{tabular}{ccccccc}
\hline Catalyst & \multicolumn{7}{c}{ Ti-CAT-I } \\
\hline $\begin{array}{c}\text { Component } \\
\text { Theoretical, } \\
\text { wt/wt \% }\end{array}$ & $\mathrm{NiO}$ & $\mathrm{CeO}_{2}$ & $\mathrm{MgO}$ & $\mathrm{TiO}_{2}$ & $\mathrm{SiO}_{2}$ & $\mathrm{Al}_{2} \mathrm{O}_{3}$ \\
$\begin{array}{c}\text { Experimental, } \\
\text { wt/wt \% }\end{array}$ & 5.00 & 10.00 & 1.00 & 3.00 & 2.00 & 79.00 \\
\hline
\end{tabular}

Table 1b. ICP metal oxide microanalysis of Ti-CAT-II.

\begin{tabular}{ccccccc}
\hline Catalyst & \multicolumn{7}{c}{ Ti-CAT-II } \\
\hline $\begin{array}{c}\text { Component } \\
\text { Theoretical, } \\
\text { wt/wt \% }\end{array}$ & $\mathbf{N i O}$ & $\mathrm{CeO}_{2}$ & $\mathbf{M g O}$ & $\mathrm{TiO}_{2}$ & $\mathrm{SiO}_{2}$ & $\mathrm{Al}_{2} \mathrm{O}_{3}$ \\
$\begin{array}{c}\text { Experimental, } \\
\text { wt/wt \% }\end{array}$ & 4.00 & 10.00 & 0.00 & 3.00 & 2.00 & 79.00 \\
\hline
\end{tabular}

\subsection{Temperature Programmed Desorption $\left(\mathrm{CO}_{2}-\mathrm{TPD}\right)$}

$\mathrm{CO}_{2}$-TPD experiment was performed to study the basicity of the catalysts. The obtained results are shown in figure 3.

Catalyst's basicity has paramount influence on the catalytic performance in DRM due to the acidic nature of $\mathrm{CO}_{2}$. Thus, strong basic sites can enhance the catalytic activity and increases the chemisorption and reaction of reacting gases [28]. Basic sites' distribution on the catalyst, i.e. weak, intermediate, strong, and very strong, correspond to peaks in the temperature ranges of $20-150^{\circ} \mathrm{C}$, $150-300^{\circ} \mathrm{C}, 300-450^{\circ} \mathrm{C}$, and $>450^{\circ} \mathrm{C}$, respectively, in $\mathrm{CO}_{2}-\mathrm{TPD}$ profile $[29,30]$.

From figure 3, all the catalysts except $5.0 \mathrm{wt} \% \mathrm{NiO} / 3.0 \mathrm{wt} \% \mathrm{TiO}_{2}-\gamma-\mathrm{Al}_{2} \mathrm{O}_{3}$ and $10.0 \mathrm{wt} \% \mathrm{CeO}_{2} / 3.0$ wt $\% \mathrm{TiO}_{2}-\gamma-\mathrm{Al}_{2} \mathrm{O}_{3}$ has equal number of basic sites appearing at almost the same different temperatures. Both $5.0 \mathrm{wt} \% \mathrm{NiO} / 3.0 \mathrm{wt} \% \mathrm{TiO}_{2}-\gamma-\mathrm{Al}_{2} \mathrm{O}_{3}$ and $10.0 \mathrm{wt} \% \mathrm{CeO}_{2} / 3.0 \mathrm{wt} \% \mathrm{TiO}_{2}-\gamma-\mathrm{Al}_{2} \mathrm{O}_{3}$ have three basic sites with one of these sites having high and strong basicity centered at a temperature around $310^{\circ} \mathrm{C}$.

For the peaks appearing at the different temperature ranges, peaks in the temperature range $50-125^{\circ} \mathrm{C}$ correspond to weak basic sites, peaks at $160-185^{\circ} \mathrm{C}$ fall under the category of intermediate strength basic sites, while the peaks at $260^{\circ} \mathrm{C}$ correspond to strong basicity site. An elbow peak was observed for all of the samples, except for $5.0 \mathrm{wt} \% \mathrm{NiO} / 3.0 \mathrm{wt} \% \mathrm{TiO}_{2}-\gamma-\mathrm{Al}_{2} \mathrm{O}_{3}$ and $10.0 \mathrm{wt} \%$ $\mathrm{CeO}_{2} / 3.0$ wt $\% \mathrm{TiO}_{2}-\gamma-\mathrm{Al}_{2} \mathrm{O}_{3}$, at temperature centered around $500^{\circ} \mathrm{C}$. This peak had no significant $\mathrm{CO}_{2}$ uptake. 


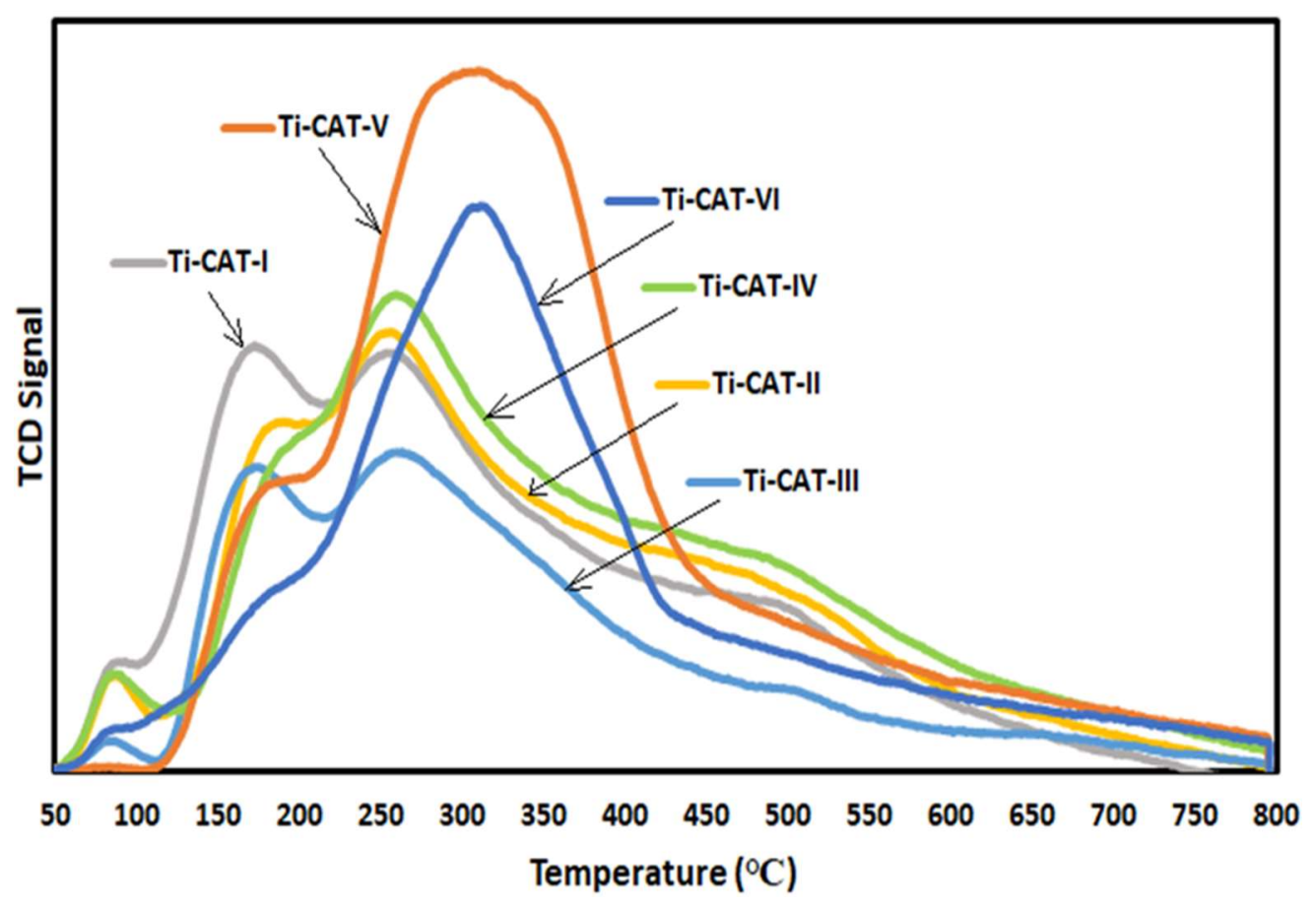

Figure 3: $\mathrm{CO}_{2}-\mathrm{TPD}$ profiles of the synthesized catalysts

\subsection{Surface Characterization}

The textural properties of the fresh catalysts were studied using nitrogen adsorptiondesorption isotherms. The results obtained from the $\mathrm{N}_{2}$ physisorption are shown in Table 2 and that of the isotherms are presented in Figure 4. The results give an insight of the variations in the activities of the catalysts. In accordance to IUPAC classifications of isotherms, the isotherms in Figure 4 fall under the category of type IV with H3-type hysteresis loop which results from capillary condensation and evaporation at high relative pressures [31]. 
Table 2: $\mathrm{N}_{2}$ physisorption results for the different catalysts

\begin{tabular}{rccc}
\hline Catalyst & $\begin{array}{c}\text { BET surface area } \\
\left(\mathbf{m}^{2} / \mathbf{g}\right)\end{array}$ & $\begin{array}{c}\text { Av. Pore diameter } \\
(\AA)\end{array}$ & Pore volume $\left(\mathbf{c m}^{3} / \mathbf{g}\right)$ \\
Ti-CAT-I & 284.18 & 115.08 & 0.40 \\
Ti-CAT-II & 283.43 & 124.45 & 0.43 \\
Ti-CAT-III & 326.20 & 117.59 & 0.43 \\
Ti-CAT-IV & 256.21 & 123.00 & 0.39 \\
Ti-CAT-V & 333.83 & 123.89 & 0.43 \\
Ti-CAT-VI & 299.17 & 125.19 & 0.40 \\
\hline
\end{tabular}

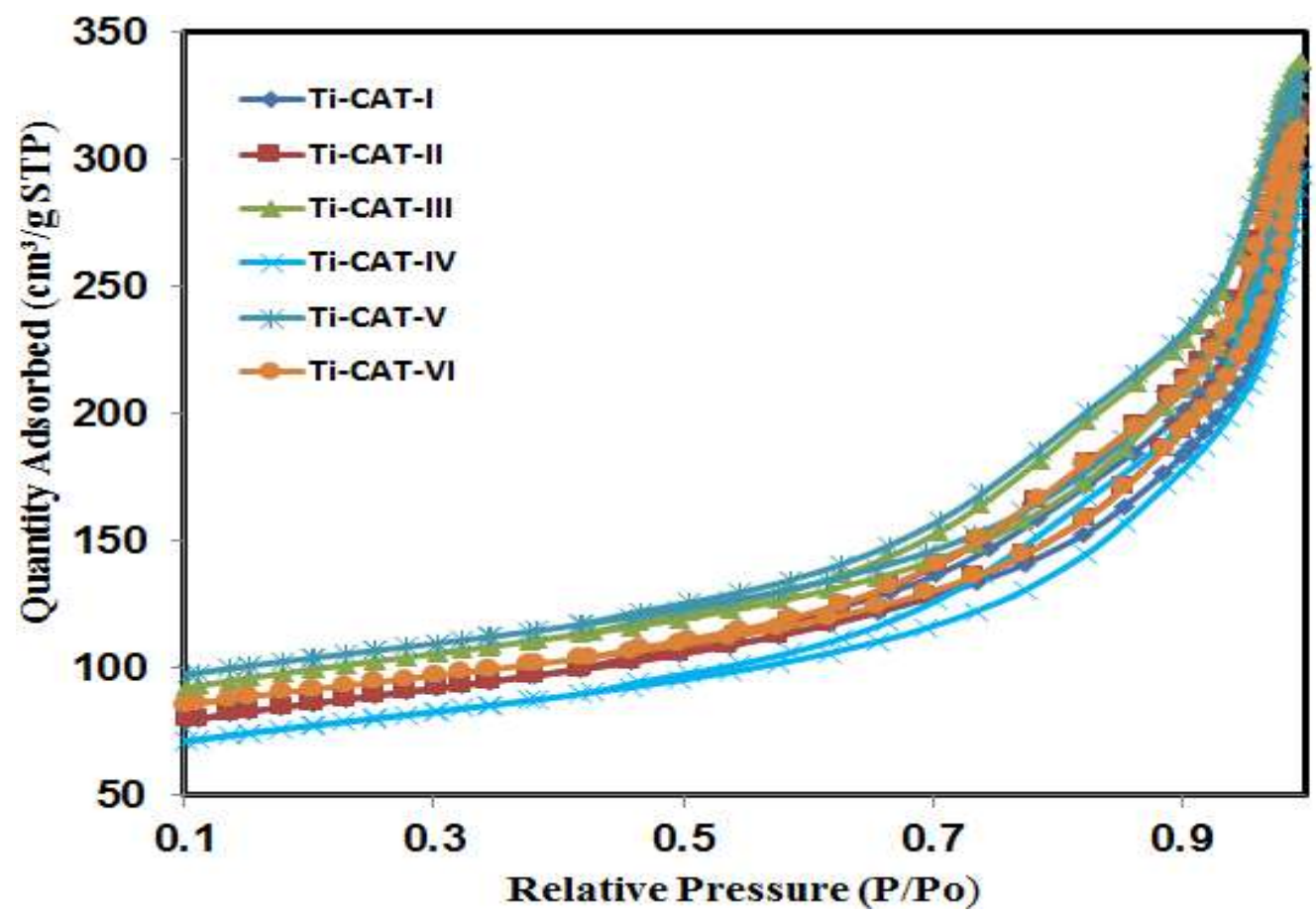

Figure 4: $\mathrm{N}_{2}$ adsorption-desorption isotherms for Ti-CAT samples

The effect of surface area variation was observed when $\mathrm{Mg}$, Ce and $\mathrm{Ni}$ were combined. Table 2 shows that the surface area of the combined metal catalysts reduced relative to single-metal catalysts. This observation is because of the combined metal deposition on the porous structure of the support and filling its pores [32]. 


\section{5. $H_{2}-T P R$ and TG Analysis}

The reduction behavior of the different catalyst samples was investigated using $\mathrm{H}_{2}$-TPR and the profiles are presented in figure 5(A). The nickel reduction peaks for Ti-CAT-x ( $x=$ I, II, III), samples containing Ni combined with other metals, are characterized by three reduction regions at low, medium and high temperature ranges, which are dependent on the degree of dispersion and interaction of the active metal with the support. From these results, the nickel phase reducibility was influenced by the combination of the metals. The reduction peak in the temperature range of $280-380^{\circ} \mathrm{C}$ could be assigned to the reduced species of $\mathrm{NiO}$ having weak interaction with the support, while the peaks that appeared in the temperature range of 600$700^{\circ} \mathrm{C}$ might be linked to the reduction of $\mathrm{NiO}$ species having strong interaction with the support, and a reduction peak of $\mathrm{Ni}^{2+}$-derived from spinel could be found at around $810^{\circ} \mathrm{C}$ [33].

For Ti-CAT-V i.e. the catalyst with only $\mathrm{Ni}$, the $\mathrm{NiO}$ reduction peaks appeared narrower, more intense in temperature ranges lower than those of combined metal counterparts.

Only two reduction peaks were noticeable for Ti-CAT-VI $\left(10.0\right.$ wt $\% \mathrm{CeO}_{2} / 3.0 \mathrm{wt} \% \mathrm{TiO}_{2}-\gamma-$ $\mathrm{Al}_{2} \mathrm{O}_{3}$ ) at temperature ranges centered at 260 and $325^{\circ} \mathrm{C}$. Similar reduction peaks are expected for $\mathrm{CeO}_{2}$ promoted samples but they appeared to have merged with the peaks for $\mathrm{NiO}$ that appeared around that temperature range.

At the end of the reaction that lasted for seven hours, the used catalysts were subjected to TGA, a quantitative analysis that determines the amount of carbon deposition. Figure 5(B) shows the result of the analysis. Catalysts, which showed no sign of reaction, were exempted from this analysis. The weight $\%$ loss for virtually all the catalysts began at around $620^{\circ} \mathrm{C}$. The TGA profiles revealed that both Ti-CAT-V and MgO-promoted catalysts had the lowest weight loss of about $15.0 \%$ carbon deposition, while the two most reactive catalysts (Ti-CAT-II and Ti-CAT-I) had the highest amount of carbon deposition of about $25.0 \mathrm{wt} \%$.

From this result, it can be inferred that the combined metal catalysts, namely Ti-CAT-II and Ti-CAT-I, only enhanced the feed conversion capacity of the catalysts and had less effect in retarding carbon deposition.

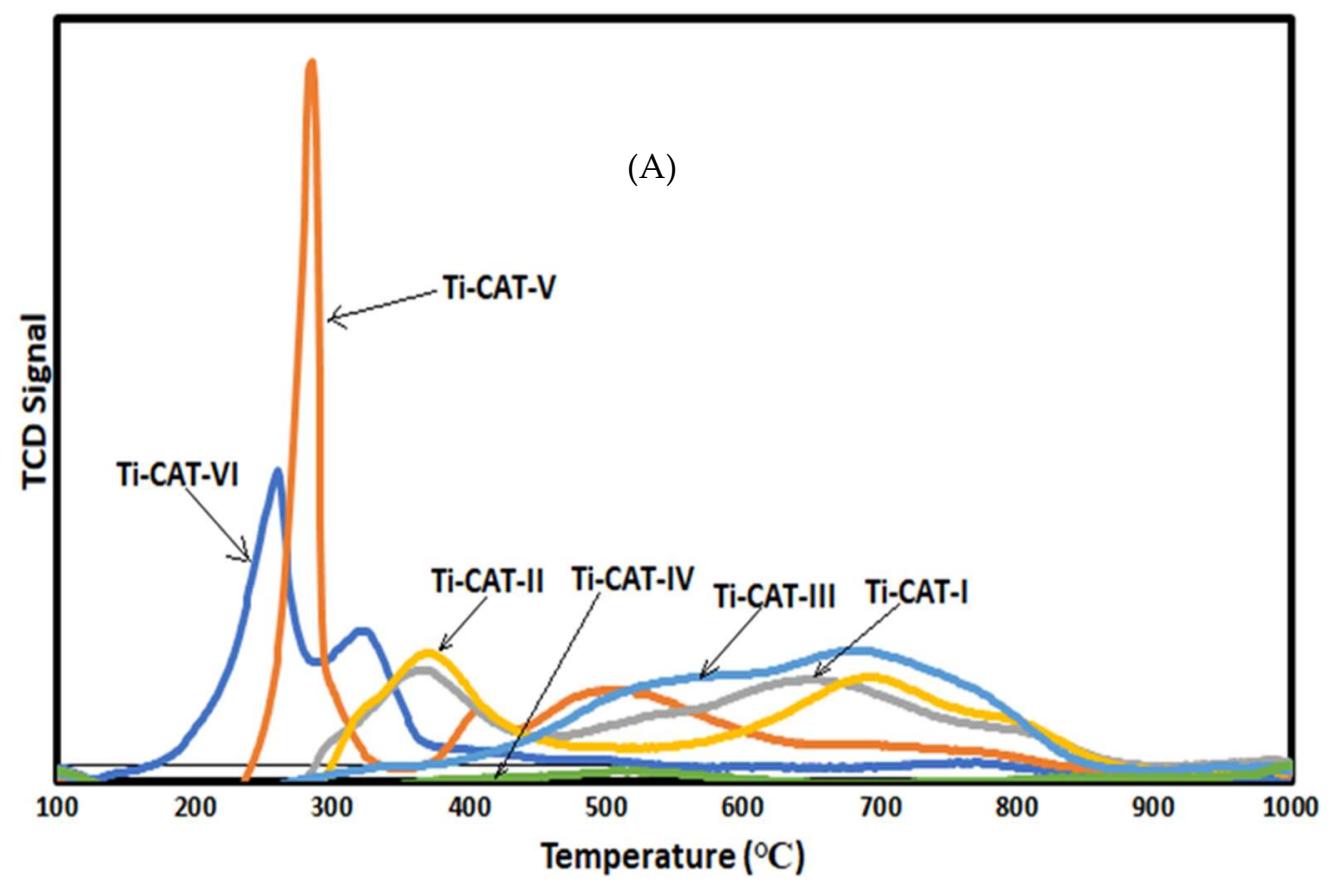




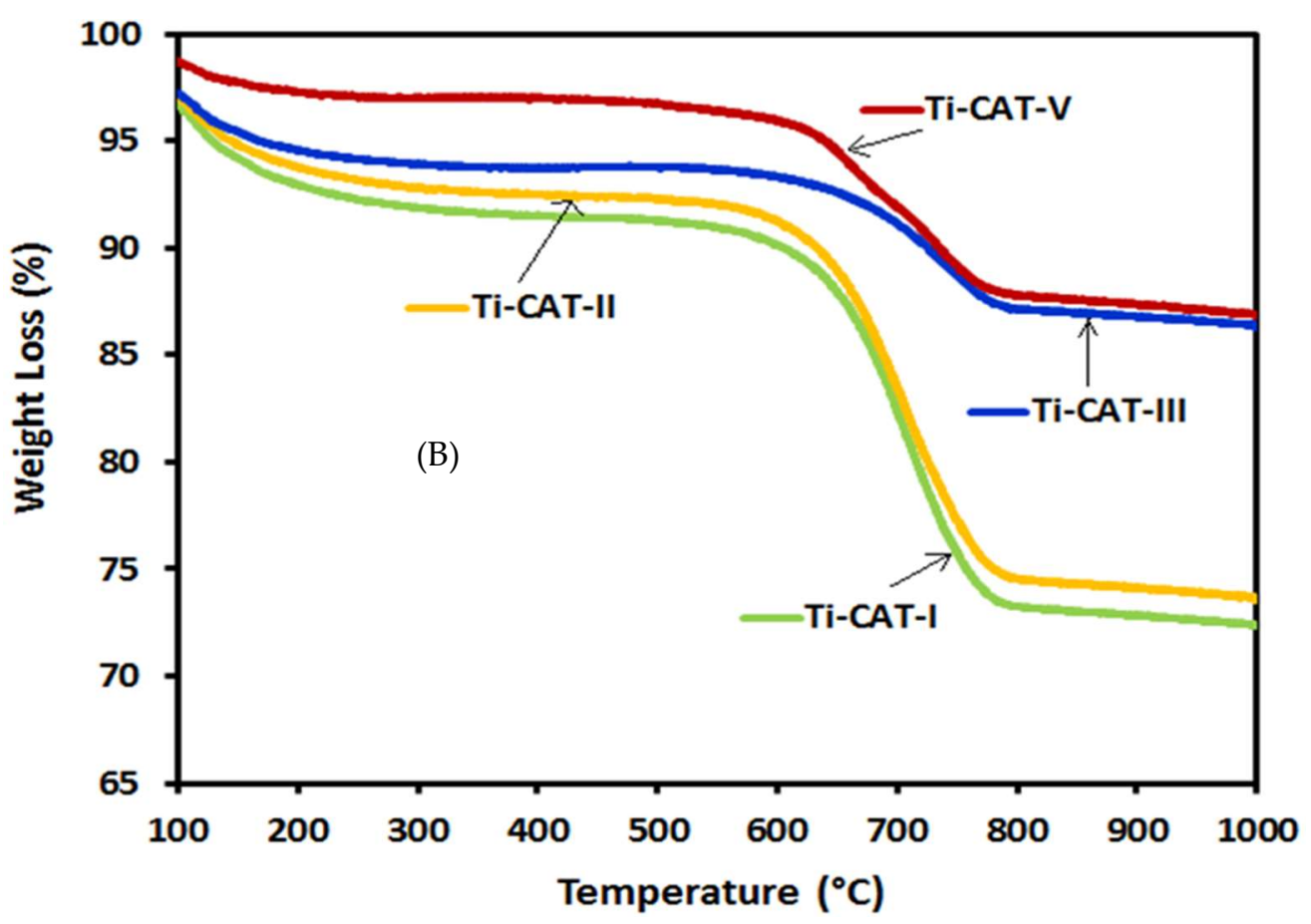

Figure 5: (A) TPR profiles of the promoted and un-promoted catalysts (B) TGA profiles for the spent catalysts

\subsection{Effect of $\mathrm{Mg}$ and Ce combination on the catalytic performance}

The effect of combining $\mathrm{CeO}_{2}$ and $\mathrm{MgO}$ on Ti-CAT-V and their catalytic performance were studied by comparing the activities of Ti-CAT-V catalyst with the those of Ti-CAT-I, Ti-CAT-II, and Ti-CAT-III. $\mathrm{CH}_{4}, \mathrm{CO}_{2}$ conversions and $\mathrm{H}_{2} / \mathrm{CO}$ mole ratio at temperature of $700^{\circ} \mathrm{C}$, for 7.0 hours' time-on-stream for DRM, were calculated and plotted as shown in Figure 6(A), (B) and (C). All the combined catalysts have $\mathrm{CH}_{4}$ and $\mathrm{CO}_{2}$ conversions higher than that of the $5 \% \mathrm{Ni} / 3 \mathrm{TiO}_{2}-\gamma-\mathrm{Al}_{2} \mathrm{O}_{3}$ catalyst except for Ti-CAT-VI and Ti-CAT-IV which showed no sign of reaction during the DRM. Ti-CAT-II had the highest $\mathrm{CH}_{4}$ conversion of about $55 \%$ at the start of the reaction and maintained stability at around $52 \%$. The high specific surface area of the catalyst $\left(283.43 \mathrm{~m}^{2} / \mathrm{g}\right)$ enhanced the adsorption, diffusion and contact of the reactant gases which were of great benefit to its catalytic performance. The high average pore diameter and pore volume of Ti-CAT-II may also be another reason for its best performance.

The same trend was observed for $\mathrm{CO}_{2}$ conversion with the Ti-Cat-V catalyst having the least conversion. For all the catalysts under investigation, $\mathrm{CO}_{2}$ conversion was observed to be higher than $\mathrm{CH}_{4}$ conversion which is suggestive of the occurrence of reverse water gas shift (RWGS) reaction. Wang et al. gave the same observation in their study on catalytic hydrogenation of carbon dioxide [34].

$$
\mathrm{H}_{2}+\mathrm{CO}_{2} \rightarrow \mathrm{CO}+\mathrm{H}_{2} \mathrm{O} \quad \Delta \mathrm{H}_{298}=+41.2 \mathrm{kj} / \mathrm{mol}
$$

In addition, the $\mathrm{H}_{2} / \mathrm{CO}$ mole ratio of values less than 1 , for all the catalysts, confirmed the occurrence of RWGS as a side reaction. 

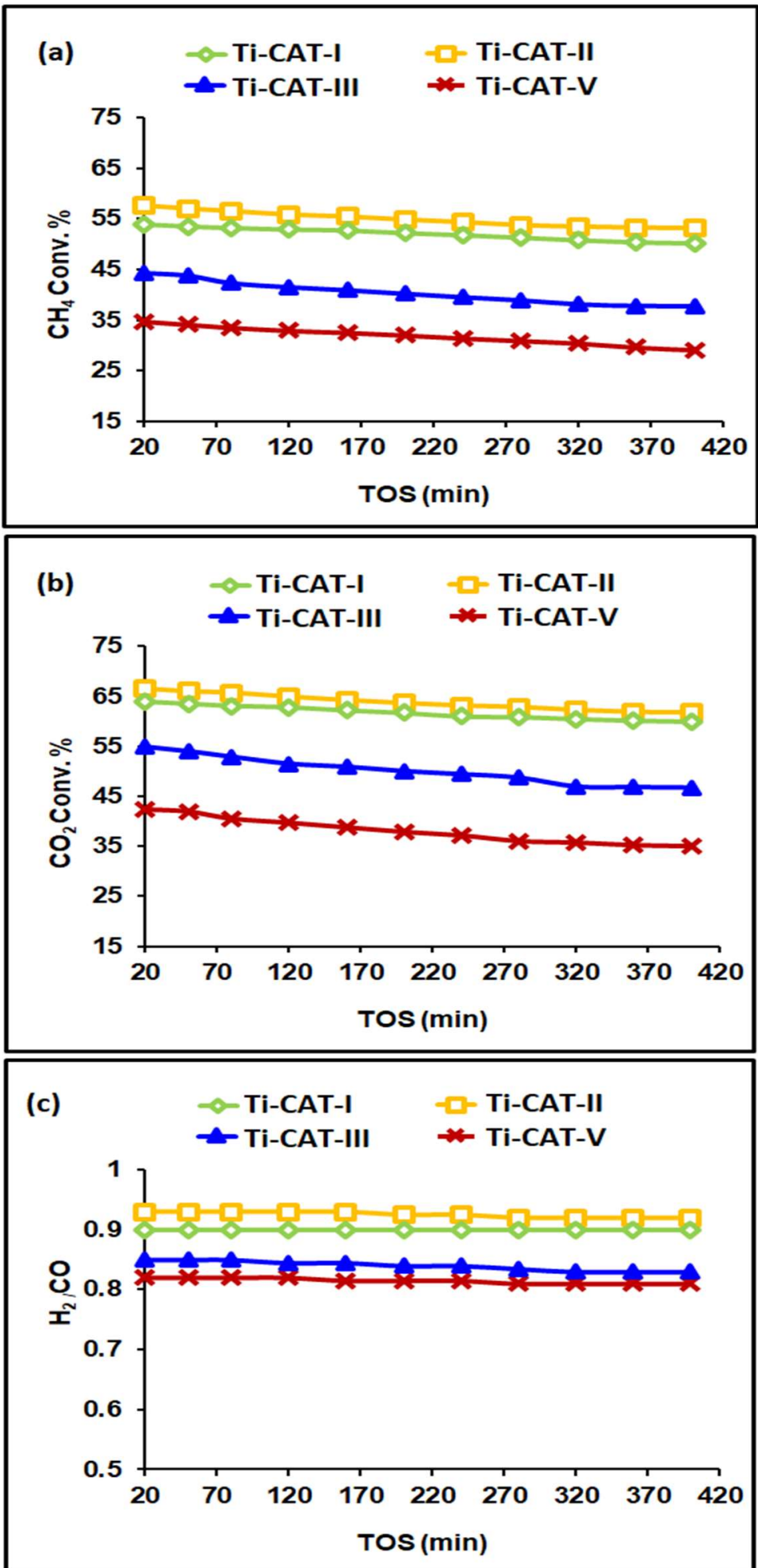

Figure 6: Catalytic performance of Ti-CAT-I, Ti-CAT-II, Ti-CAT-III, and Ti-CAT-V (A) $\mathrm{CH}_{4}$ conversion (B) $\mathrm{CO}_{2}$ conversion and $(\mathrm{C}) \mathrm{H}_{2} / \mathrm{CO}$ ratio 
Ti-CAT-II catalyst resulted in a $\mathrm{H}_{2} / \mathrm{CO}$ mole ratio value closest to 1 than any of the tested catalysts. The desirable value of the syngas ratio suitable for downstream Fischer-Tropsch synthesis of valuable chemicals is one [35], thus making it the best option for the dry reforming.

\subsection{Effect of space velocity}

The effect of gas hourly space velocity (GHSV) was studied on the catalyst that showed the best performance in the previous section (i.e. Ti-CAT-II catalyst). GHSV of 19,500 and $78,000 \frac{\text { feed flow rate }}{\text { mass of cat. }}\left(\frac{\mathrm{ml}}{\mathrm{g} . \mathrm{hr}}\right)$ were considered at $700^{\circ} \mathrm{C}$ and time on stream over 7.0 hours for DRM, while keeping the mass of the catalyst constant. These GHSV values were as half and twice as of the initial GHSV of $39,000\left(\mathrm{ml} \mathrm{g}^{-1} \mathrm{hr}^{-1}\right)$ respectively. The results in terms of $\mathrm{CO}_{2}$ and $\mathrm{CH}_{4}$ conversions as well as $\mathrm{H}_{2} / \mathrm{CO}$ mole ratio were calculated and plotted in figures 7(A) and (B). As the GHSV increased, the $\mathrm{CH}_{4}$ and $\mathrm{CO}_{2}$ conversions decreased with the highest conversions for both $\mathrm{CH}_{4}$ and $\mathrm{CO}_{2}$ obtained at GHSV of 19,500 $\frac{\text { feed flow rate }}{\text { mass of cat. }}\left(\frac{\mathrm{ml}}{\mathrm{g} \cdot \mathrm{hr}}\right)$. The decrease in conversions can be attributed to the feed having less residence time at higher GHSV [36]. A similar trend was observed with $\mathrm{H}_{2} / \mathrm{CO}$ mole ratio, where it decreased from a ratio of 1 to around 0.8 . However, the results at GHSV of 39,000 were the most stable in comparison to those obtained at the other GHSV values.
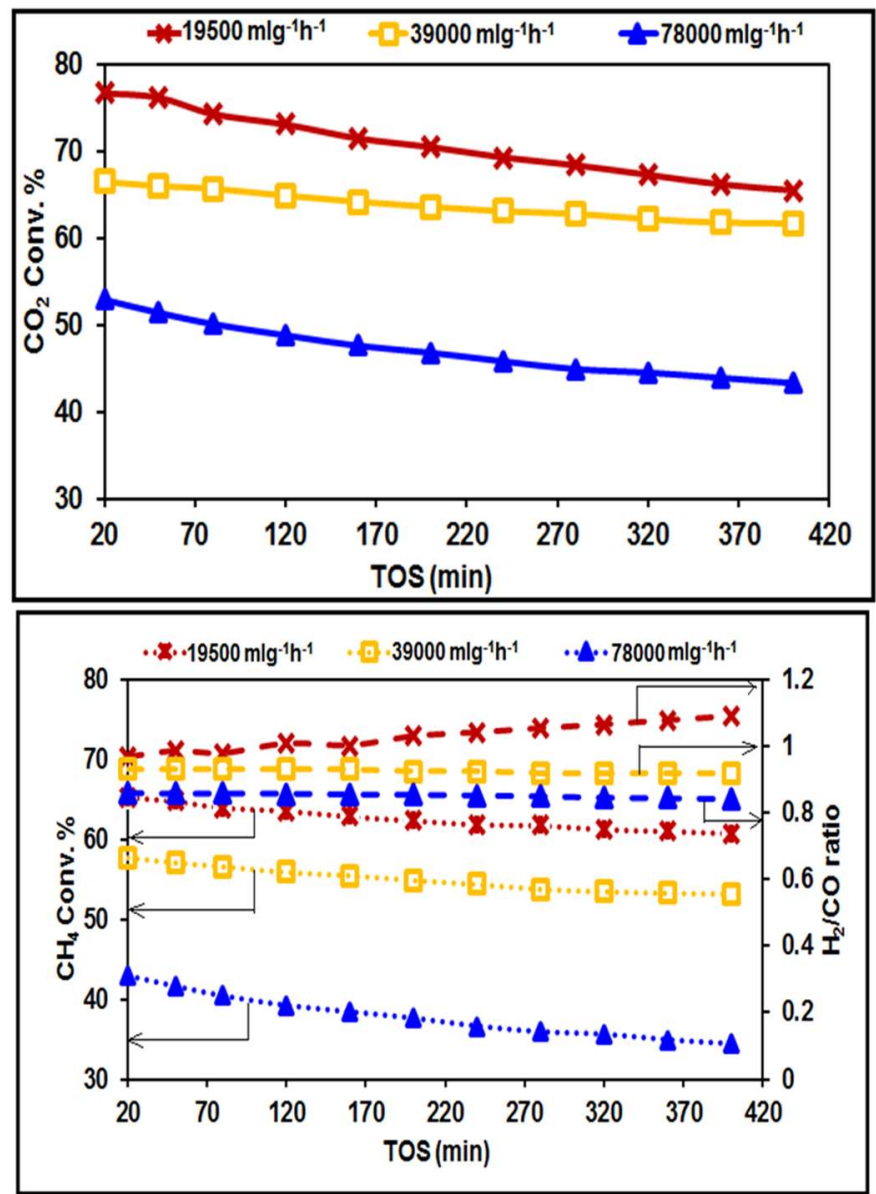

Figure 7: (A) $\mathrm{CO}_{2}$ conversion for Ti-CAT-II at different gas hourly space velocity (B) $\mathrm{CH}_{4}$ and $\mathrm{H}_{2} / \mathrm{CO}$ ratio for Ti-CAT-II catalyst at different space velocity 


\subsection{Effect of GHSV on Carbon Deposition}

Quantitative analysis of carbon deposition was performed on the catalyst Ti-CAT-II used in methane dry reforming at 3 different space velocities 19,500, 39,000 and 78,000 $\left(\mathrm{ml} \mathrm{g}^{-1} \mathrm{hr}^{-1}\right)$.

The results obtained after the completion of the reactions are shown in figure 8 . The analysis for the reaction performed at $19500 \mathrm{ml} /(\mathrm{g} . \mathrm{h})$ showed the least amount of carbon deposition of about $18 \%$, proving that the DRM took place and not thermal decomposition at this GHSV. The reactions carried out at 39,000 and 78,000 ml/(g.h) showed relatively higher carbon deposition of about 26 and 25\%, respectively, indicating that the catalyst had little effect on methane conversion due to the lack of much contact time at these GHSV values and the conversion was mostly by thermal decomposition.

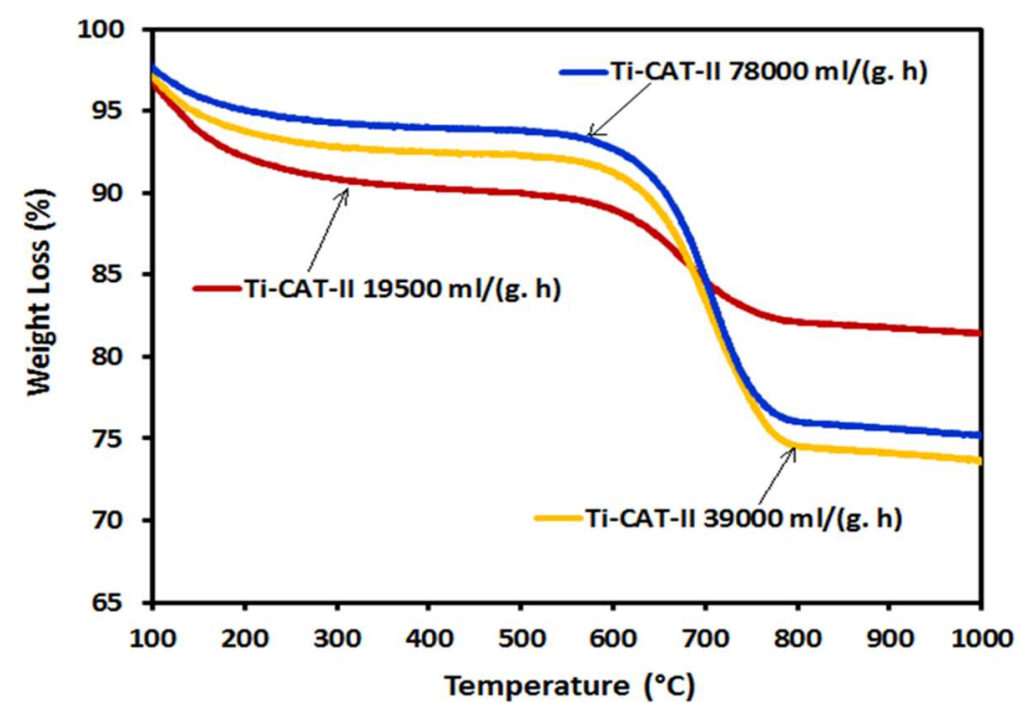

Figure 8: TGA curves for Ti-Cat-II at 19,500, 39,000 and 78,000 ml/ (g.h) GHSV values.

\subsection{Effect of different $\mathrm{CO}_{2} / \mathrm{CH}_{4}$ ratios}

The mole ratio of $\mathrm{CO}_{2}$ to $\mathrm{CH}_{4}$ was varied at a fixed total flow rate to study the performance of Ti-CAT-II catalyst when $\mathrm{CH}_{4}$ was supposed to act as the limiting reagent in excess of $\mathrm{CO}_{2}$ at $700^{\circ} \mathrm{C}$ and 39,000 ml/(g. h) GHSV. The results are shown in figure 9 (a), (b) and (c). The highest $\mathrm{CH}_{4}$ conversion of about $78 \%$ was obtained when $\mathrm{CO}_{2}$ was in $20 \%$ excess of $\mathrm{CH}_{4}$, while the least conversion of $\mathrm{CH}_{4} \cong 43 \%$ resulted when the amount of $\mathrm{CO}_{2}$ was $50 \%$ of the required stoichiometric amount in the feed. This observation was expected as $\mathrm{CH}_{4}$ would have enough $\mathrm{CO}_{2}$ to undergo dry reforming. On the other hand, the highest $\mathrm{CO}_{2}$ conversion of $\cong 90 \%$ was observed when $\mathrm{CO}_{2}$ was the limiting reagent. This observation could be due to excess $\mathrm{CH}_{4}$ present in the feed. The $\mathrm{CO}_{2}$ conversion reduced with the reaction time-on-stream. Such observation could be ascribed to the disproportionation of carbon monoxide into $\mathrm{CO}_{2}$ and graphite, a transformation known as Boudouard reaction:

$$
2 \mathrm{CO}(\mathrm{g})=\mathrm{CO}_{2(\mathrm{~g})}+\mathrm{C}_{(\mathrm{s})}
$$

Comparing the different $\mathrm{CO}_{2} / \mathrm{CH}_{4}$ ratios, it was observed that $\mathrm{CH}_{4}$ conversion increased with the ratio up to 1.2 (i.e. $0.5<1.0<1.2$ ) and then declined slightly at 1.5 . however, the conversion for $\mathrm{CO}_{2}$ was seen to be decreasing as the ratio was increased (i.e. $1.5<1.2<1.0<0.5$ ). 
Figure 9(c) displays the $\mathrm{H}_{2} / \mathrm{CO}$ mole ratio results. It was observed that at the lowest $\mathrm{CO}_{2} / \mathrm{CH}_{4}$ mole ratio, the $\mathrm{H}_{2} / \mathrm{CO}$ mole ratio was more than one. This observation could be owing to the insufficient amount of $\mathrm{CO}_{2}$ for complete dry reforming of the available $\mathrm{CH}_{4}$ and to the thermal decomposition of unreformed $\mathrm{CH}_{4}$, giving more $\mathrm{H}_{2}$ than the stoichiometric amount. Moreover, the Boudouard reaction might contribute to the increase of hydrogen production because the formed $\mathrm{CO}_{2}$ from Boudouard reaction would shift the DRM equilibrium to the right side.

On the other hand, $\mathrm{H}_{2} / \mathrm{CO}$ mole ratio was close to one of the cases where $\mathrm{CO}_{2}$ was in excess of $\mathrm{CH}_{4}$, where it was noticed that the $\mathrm{H}_{2} / \mathrm{CO}$ mole ratio increased with the reaction time-onstream. Once again, the Boudouard reaction might be responsible for such observation.

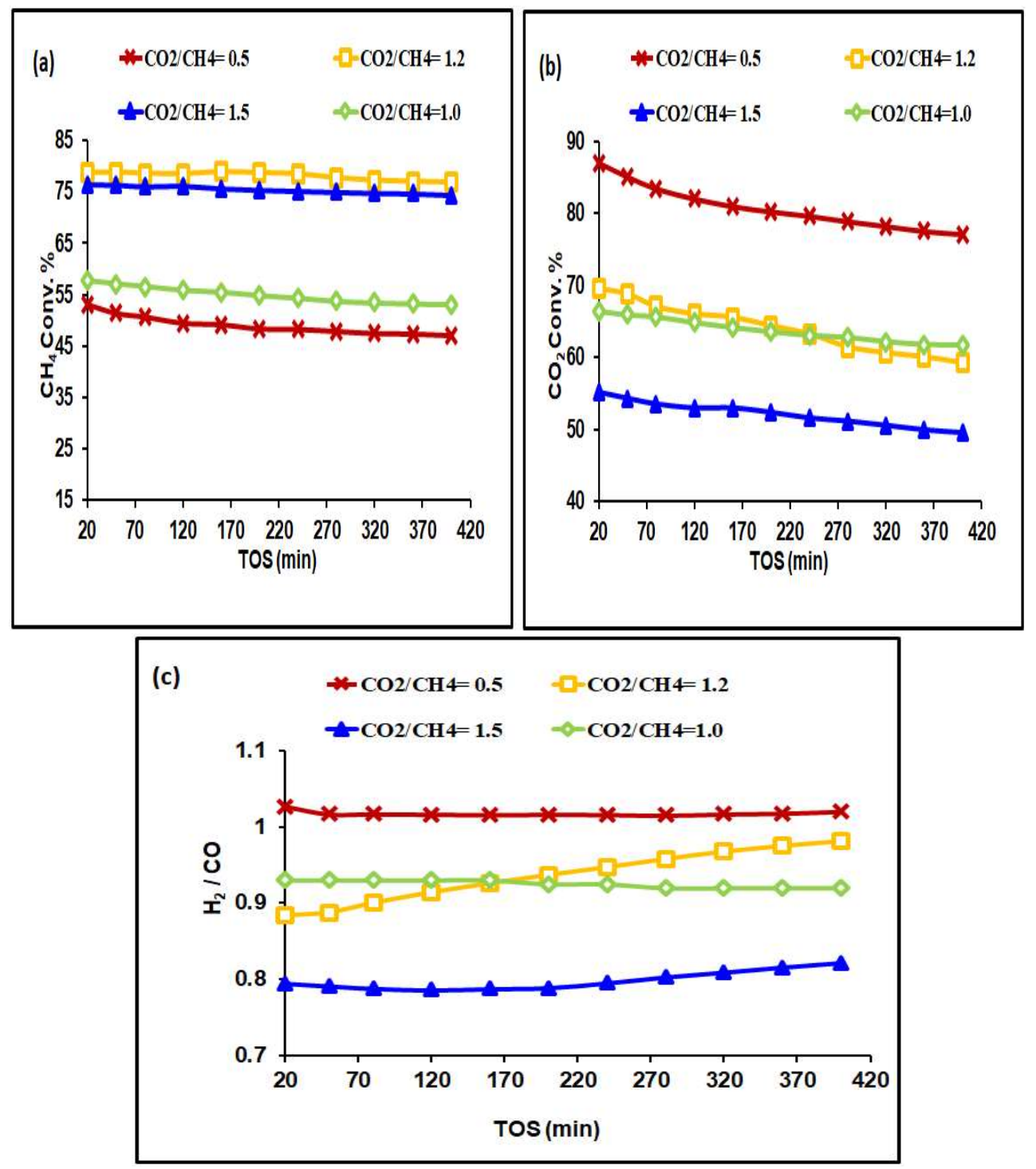

Figure 9: (a) $\mathrm{CH}_{4}$ (b) $\mathrm{CO}_{2}$ conversions and (c) $\mathrm{H}_{2} / \mathrm{CO}$ ratio for different $\mathrm{CO}_{2} / \mathrm{CH}_{4}$ ratio 


\section{Experimental Section}

\subsection{Materials}

Nickel nitrate hexahydrate $\left[\mathrm{Ni}\left(\mathrm{NO}_{3}\right)_{2} .6 \mathrm{H}_{2} \mathrm{O}, 98 \%\right.$, Alfa Aesar], cerium nitrate hexahydrate [Ce $\left(\mathrm{NO}_{3}\right)_{3} .6 \mathrm{H}_{2} \mathrm{O}, 99.0 \%$ assay on Ce basis, general purpose reagent, $\mathrm{BDH}$ ], magnesium acetate tetra-hydrate $\left[\mathrm{Mg}\left(\mathrm{O}_{2} \mathrm{CCH}_{3}\right) 2.4 \mathrm{H}_{2} \mathrm{O}, 99.5-102.0 \%\right.$, Merck] were commercially available and were used without further purification. $\gamma$-Alumina doped with titania $\left(3.0 \mathrm{wt} \% \mathrm{TiO}_{2} / \gamma-\mathrm{Al}_{2} \mathrm{O}_{3}\right)$ in the shape of pellets, was a gift from Dr. Tiancun Xiao, Senior Research Fellow, Inorganic Chemistry Laboratory, Oxford University. Ultrapure deionized water $(18.2 \mathrm{M} \Omega . \mathrm{cm})$ was obtained from a Milli-Q water purification system (Millipore).

\subsection{Catalyst Preparation}

The required amounts of $\mathrm{Ni}\left(\mathrm{NO}_{3}\right)_{2} \cdot 6 \mathrm{H}_{2} \mathrm{O}$, $\mathrm{Ce}\left(\mathrm{NO}_{3}\right)_{3} \cdot 6 \mathrm{H}_{2} \mathrm{O}, \mathrm{Mg}\left(\mathrm{O}_{2} \mathrm{CCH}_{3}\right)_{2} \cdot 4 \mathrm{H}_{2} \mathrm{O}$, and support were mixed and were ground together to fine powder by pestle and mortar. Small amount of ultrapure water was used to convert the solid mixture into a paste, which was spun mechanically until dryness. The paste and spinning process was repeated three times. The final solid was calcined in a digital, programed muffle furnace at $600^{\circ} \mathrm{C}$ for three hours by ramping temperature from room temperature by a rate of $3.0^{\circ} \mathrm{C} /$ minute. The denotation of the prepared catalyst samples and their wt \% loadings of nickel oxide, ceria, and magnesia at $600^{\circ} \mathrm{C}$ calcination are given below in Table 3.

Table 3: Prepared catalyst samples and the wt $\%$ of their composition

\begin{tabular}{llll}
\hline \multirow{2}{*}{ Catalyst } & \multicolumn{3}{c}{ Concentration, wt \% } \\
\hline Ti-CAT-I & 5.0 & 10.0 & $\mathrm{MgO}$ \\
Ti-CAT-II & 5.0 & 10.0 & 0.0 \\
Ti-CAT-III & 5.0 & 0.0 & 1.0 \\
Ti-CAT-IV & 0.0 & 10.0 & 1.0 \\
Ti-CAT-V & 5.0 & 0.0 & 0.0 \\
Ti-CAT-VI & 0.0 & 10.0 & 0.0 \\
\hline
\end{tabular}

\subsection{Catalyst Characterization}

The metallic component composition of all catalysts was determined by an Agilent 7800 inductively-coupled plasma mass spectrometry (ICP) at the laboratory of IDAC Merieux NutriSciences, Riyadh, Saudi Arabia. Carbon deposition on the used catalysts was measured by thermogravimetric analysis (TGA) under air by using a Shimadzu TGA-51. A certain amount from the spent catalyst $(10 \mathrm{mg}$ ) was subjected to heat treatment within the temperature range $25^{\circ} \mathrm{C}-1000^{\circ} \mathrm{C}$. Ramping temperature was maintained at $20^{\circ} \mathrm{C} / \mathrm{min}$. The Brunauer-Emmet-Teller technique was adopted in calculating the surface area per unit mass of the samples using a device 
that analyses surface area and porosity i.e. Micromeritics Tristar II 3020. For nitrogen physisorption measurements, an amount of $0.20-0.30 \mathrm{~g}$ weighed from the catalyst was subjected to degassing at $300^{\circ} \mathrm{C}$ for three hours prior to analysis. The reducibility of the fresh catalysts was determined by the Micromeritics AutoChem II. A sample weight of $75.0 \mathrm{mg}$ was analyzed. Samples were first heated under argon $(99.9 \%)$ at $150^{\circ} \mathrm{C}$ for $30 \mathrm{~min}$, thereafter cooled to $25^{\circ} \mathrm{C}$. Afterwards, samples were heated to $1000^{\circ} \mathrm{C}$ at $10^{\circ} \mathrm{C} / \mathrm{min}$ by allowing the flow of $10 \% \mathrm{H}_{2} / \mathrm{Ar}$ gas at $40 \mathrm{ml} / \mathrm{min}$. A thermal conductivity detector (TCD) was used to follow the $\mathrm{H}_{2}$ consumption. Temperature programmed desorption of carbon dioxide ( $\left.\mathrm{CO}_{2}-\mathrm{TPD}\right)$ and $\mathrm{CO}$ pulse chemisorption measurements were obtained from an automatic chemisorption equipment (Micromeritics AutoChem II 2920) with a TCD. At the start a $70 \mathrm{mg}$ sample was heated at $200^{\circ} \mathrm{C}$ for $1 \mathrm{~h}$ under helium (He) flow to remove adsorbed components. Then, $\mathrm{CO}_{2}$ adsorption was carried out at $50^{\circ} \mathrm{C}$ for $60 \mathrm{~min}$ in the flow of $\mathrm{He} / \mathrm{CO}_{2}$ gas mixture $(90 / 10 \mathrm{~L} / \mathrm{L})$ with a flow rate of $30.0 \mathrm{ml} / \mathrm{min}$. Afterward, a linear temperature rise at a rate of $10^{\circ} \mathrm{C} / \mathrm{min}$ until $800^{\circ} \mathrm{C}$ was registered by the TCD of $\mathrm{CO}_{2}$ desorption signal. X-ray powder diffraction patterns for the samples were recorded on a Bruker D8 Advance XRD diffractometer by using $\mathrm{Cu} \mathrm{K}_{\alpha}$ radiation source and a nickel filter, operated at $40 \mathrm{kV}$ and $40 \mathrm{~mA}$. The step size and scanning range of $2 \theta$ for analysis was set to $0.01^{\circ}$ and $5-100^{\circ}$, respectively. The present phases were documented using standard powder XRD cards (JCPDS). Catalysts' morphology was studied using JEOL JSM-7100F field emission scanning electron microscope, equipped with energy-dispersive X-ray spectroscopy (EDXS) for surface elemental analysis.

\subsection{Catalystic Perfromance}

Methane reforming reaction was accomplished in a fixed-bed tubular stainless steel microreactor $(\mathrm{ID}=9 \mathrm{~mm}$ ) at atmospheric pressure. The reactor system was provided by process integral development (PID Eng. \& Tech). Before performing the DRM reaction, a $0.10 \mathrm{~g}$ catalyst was activated by $\mathrm{H}_{2}$ flow of $40 \mathrm{ml} / \mathrm{min}$ at $700{ }^{\circ} \mathrm{C}$ for 60 minutes. $\mathrm{N}_{2}$ gas was then admitted to the reactor for $20 \mathrm{~min}$ to remove adsorbed $\mathrm{H}_{2}$ while the catalyst was kept at reaction temperature $\left(700^{\circ} \mathrm{C}\right)$. Afterwards, feed gases of $\mathrm{CH}_{4}, \mathrm{CO}_{2}$, and $\mathrm{N}_{2}$ were injected at flow rates of 35,35 and $5 \mathrm{ml} / \mathrm{min}$, respectively. The temperature, pressure and reaction variables were inspected through the reactor panel. A GC (GC-2014 SHIMADZU) unit having a thermal conductivity detector and two columns, Porapak Q and Molecular Sieve 5A, was connected in series/bypass connections in order to have a complete analysis of the reaction products. The following equations were used to calculate the $\mathrm{CH}_{4}$ and $\mathrm{CO}_{2}$ conversions respectively.

$$
\begin{aligned}
& \% \mathrm{CH}_{4} \text { conversion }=\frac{\mathrm{CH}_{4} \text { in }-\mathrm{CH}_{4} \text { out }}{\mathrm{CH}_{4} \text { in }} \times 100 \\
& \% \mathrm{CO}_{2} \text { conversion }=\frac{\mathrm{CO}_{2} \text { in }-\mathrm{CO}_{2} \text { out }}{\mathrm{CO}_{2} \text { in }} \times 100
\end{aligned}
$$

\section{Conclusions}

This paper investigated the dry reforming of methane, $\mathrm{CH}_{4}$, over $5.0 \mathrm{wt} \% \mathrm{NiO} / 3.0 \mathrm{wt} \%$ $\mathrm{TiO}_{2}+\gamma-\mathrm{Al}_{2} \mathrm{O}_{3}$ catalyst, Ti-CAT-V, and the effects of promoters such as $\mathrm{CeO}_{2}$ and $\mathrm{MgO}$, on the catalytic activity and stability of the catalyst. The promoter loading was $10.0 \mathrm{wt} \%$ and $1.0 \mathrm{wt} \%$ for $\mathrm{CeO}_{2}$ and $\mathrm{MgO}$ respectively. Promoted Ti-CAT-V catalyst showed better conversion of both $\mathrm{CH}_{4}$ and $\mathrm{CO}_{2}$ than the un-promoted counterpart. $5.0 \mathrm{wt} \% \mathrm{Ni}$. O- $10.0 \mathrm{wt} \% \mathrm{CeO}_{2} / 3.0 \mathrm{wt} \% \mathrm{TiO}_{2}+\gamma-\mathrm{Al}_{2} \mathrm{O}_{3}$ had the highest $\mathrm{CH}_{4}$ and $\mathrm{CO}_{2}$ conversion of about $55 \%$ and $64 \%$ respectively, while no reaction was observed for 10.0 wt $\% \mathrm{CeO}_{2} / 3.0 \mathrm{wt} \% \mathrm{TiO}_{2}+\gamma-\mathrm{Al}_{2} \mathrm{O}_{3}$ and $10.0 \mathrm{wt} \% \mathrm{CeO}_{2}+1.0 \mathrm{wt} \% \mathrm{MgO} / 3.0 \mathrm{wt} \%$ 
$\mathrm{TiO}_{2}+\gamma-\mathrm{Al}_{2} \mathrm{O}_{3}$. It can be inferred from the improved performance of the promoted catalysts that the promoters had a positive influence on the textural properties, metal support interaction and reduction behaviour of the catalyst. These impacts of promoters were well shown by the used characterization techniques used. From the thermogravimetric analysis, un-promoted catalyst gave the lowest carbon deposition. This result implied that the promoters only enhanced the performance of the catalyst and had less effect in retarding carbon deposition relative to the unpromoted catalyst.

Ti-CAT-V was selected for further investigation at different GHSVs and subsequently at various $\mathrm{CO}_{2} / \mathrm{CH}_{4}$ ratios. An inverse relationship between GHSV and catalytic activity was observed. A GHSV of $19500 \frac{\text { feed flow rate }}{\text { mass of cat. }}\left(\frac{\mathrm{ml}}{\mathrm{g} \cdot \mathrm{hr}}\right)$ and $\mathrm{CO}_{2} / \mathrm{CH}_{4}$ ratio of 0.5 gave the best results.

Author Contributions: A.S.F., A.H.F, S.O.K., R.Ar., R.As. and A.B. carried out all experiments and characterization tests as well as shared in the analysis of the data and shared in the writing of the manuscript. A.S.F, S.O.K, A.E.A and A.B. wrote the paper and shared data analysis. A.H.F and A.A.I. contributed in writing the paper and edited it.

Funding: This research was funded by the Deanship of Scientific Research at King Saud University, Project No. RGP-1435-078.

Acknowledgments: The authors would like to express their sincere appreciation to the Deanship of Scientific Research at King Saud University for its funding for this research group project No. (RG-1435-078)

Conflicts of Interest: The authors declare no conflict of interest.

\section{References}

1. Albarazi, A.; Beaunier, P.; Da Costa, P. Hydrogen and syngas production by methane dry reforming on SBA-15 supported nickel catalysts: On the effect of promotion by $\mathrm{Ce} 0.75 \mathrm{Zr} 0.25 \mathrm{O}_{2}$ mixed oxide. Int. J. Hydrog. Energy 2013, 38, 127-139.

2. Bao, Z.; Lu, Y.; Han, J.; Li, Y.; Yu, F. Highly active and stable Ni based bimodal pore catalysts for dry reforming of methane. Appl. Catal. A Gen. 2015, 491, 116-126.

3. Buelens, L.C.; Galvita, V.V.; Poelman, H.; Detavernier, C.; Marin, G.B. Super-dry reforming of methane intensifies $\mathrm{CO}_{2}$ utilization via Le Chatelier's principle. Science 2016, 354, 449-452.

4. Julián-Durán, L.M.; Ortiz-Espinoza, A.P.; El-Halwagi, M.M.; Jiménez-Gutiérrez, A. ACS Sustain. Chem. Eng. 2014, 2, 2338-2344.

5. Schulz, H. Short history and present trends of Fischer-Tropsch synthesis. Appl. Catal. A Gen. 1999, 186, 3-12.

6. Sheu, E.J.; Mokheimer, E.M.A.; Ghoniem, A.F. A review of solar methane reforming systems. Int. J. Hydrog. Energy 2015, 40, 12929-12955.

7. Barelli, L.; Bidini, G.; Gallorini, F.; Servili, S. Hydrogen production through sorption-enhanced steam methane reforming and membrane technology. Energy 2008, 33, 554-570.

8. Hyunjin, Ji.; Junghun, L.; Eunyeong, C.; Ilsung, S. Hydrogen production from steam reforming using an indirect heating method. Int. J. Hydrog. Energy 2018, 43, 3655-3663.

9. Cyril, P.; Wenhao, $\quad$ F.; Mickaël, $\quad$ C.; Sébastien, $\quad$ P.; Louise, $\quad$ J.D. Steam reforming, partial oxidation and oxidative steam reforming for hydrogen production from ethanol over cerium nickel based oxyhydride catalyst. Appl. Catal. A Gen. 2016, 518, 78-86.

10. Yousri, M.A.W.; Mohamed, M.E.G.; Nader, R.A. Steam and partial oxidation reforming options for hydrogen production from fossil fuels for PEM fuel cells. AEJ 2012, 51, 69-75.

11. Devin, M.W.; Sandra, L.P.; John, T.W.; John, N.K. Synthesis gas production to desired hydrogen to carbon monoxide ratios by tri-reforming of methane using $\mathrm{Ni}-\mathrm{MgO}-(\mathrm{Ce}, \mathrm{Zr}) \mathrm{O}_{2}$ catalysts. Appl. Catal. A Gen. 2012, 445-446, 61-68. 
12. Linus, A.S.; Lea, C.S.K.; Karla, H.D.; Stephan, A.S.; Johannes, A. L. On the coke deposition in dry reforming of methane at elevated pressures. Appl. Catal. A Gen. 2015, 504, 599-607.

13. Drif, A.; Bion, N.; Brahmi, R.; Ojala, S.; Pirault-Roy, L.; Turpeinen, E.; Seelam, P.K; Keiski, R.L.; Epron, F. Study of the dry reforming of methane and ethanol using Rh catalysts supported on doped alumina. Appl. Catal. A Gen. 2015, 504, 576-584.

14. Jabbour, K.; El Hassan, N.; Casale, S.; Estephane, J.; El Zakhem, H. Promotional effect of Ru on the activity and stability of Co/SBA-15 catalysts in dry reforming of methane. Int. J. Hydrog. Energy 2014, 39, 7780-7787.

15. Du, X.; France, L. J.; Kuznetsov, V. L.; Xiao, T.; Edwards, P. P.; AlMegren, H.; Bagabas, A. Dry Reforming

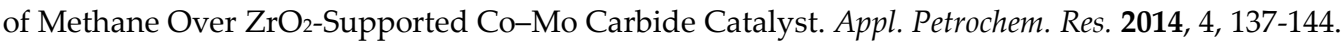

16. France, L.J.; Du, X.; Almuqati, N.; Kuznetzov, V.L.; Zhao, Y.; Zheng, J.; Xiao, T.; Bagabas, A.; Almegren, H.; Edwards, P.P. The Effect of Lanthanum Addition on The Catalytic Activity of $\gamma$-Alumina Supported Bimetallic Co-Mo Carbides for Dry Methane Reforming. Appl. Petrochem. Res. 2014, 4, 145-156.

17. Tao, X.; Wang, G.; Huang, L.; Li, X.; Ye, Q. Effect of Cu-Mo Activities on the $\mathrm{NiCuMo} / \mathrm{Al}_{2} \mathrm{O}_{3}$ Catalyst for $\mathrm{CO}_{2}$ Reforming of methane. Catal. Lett. 2016, 146, 2129-2138.

18. Budiman, A.W.; Song, S.-H.; Chang, T.-S.; Shin, C.-H.; Choi, M.-J. Dry reforming of methane over cobalt catalysts: a literature review of catalyst development. Catal. Surv. Asia 2012, 16, 183-197.

19. Park, J.H.; Lee, D.; Lee, H.C.; Park, E.D. Steam reforming of liquid petroleum gas over Mn-promoted $\mathrm{Ni} / \gamma-\mathrm{Al}_{2} \mathrm{O}_{3}$ catalysts. Korean J. Chem. Eng. 2010, 27, 1132-1138.

20. Gao, X.; Bare, S.R.; Fierro, J.L.G.; Banares, M.A.; Wachs, I.E. Preparation and in-Situ Spectroscopic Characterization of Molecularly Dispersed Titanium Oxide on Silica. J. Phys. Chem. B 1998, 102, 56535666.

21. Klein, S.; Thorimbert, S.; Maier, W.F. Amorphous microporous titania-silica mixed oxides: preparation, characterization, and catalytic redox properties. J. Catal. 1996, 163, 476-488.

22. Miller, J.B.; Ko, E.I. Control of mixed oxide textural and acidic properties by the sol-gel method. Catal. Today 1997, 35, 269-292.

23. Niu, F.; Li, S.; Zong, Y.; Yao, Q. Catalytic Behavior of Flame-Made Pd/TiO2 Nanoparticles in Methane Oxidation at Low Temperatures. J. Phys. Chem. C 2014, 118, 19165-19171.

24. Tauster, S.J.; Fung, S.C.; Baker, R.T.K.; Horsely, J.A. Partial Oxidation of Methane to Synthesis Gas over $\mathrm{Ru} / \mathrm{TiO}_{2}$ Catalysts: Effects of Modification of the Support on Oxidation State and Catalytic Performance. Science, 1981, 211, 1121-1125.

25. Shamskar, F.R.; Meshkani, F.; Rezaei, M. Preparation and characterization of ultrasound-assisted coprecipitated nanocrystalline La-, $\mathrm{Ce}-, \mathrm{Zr}$-promoted $\mathrm{Ni}_{-} \mathrm{Al}_{2} \mathrm{O}_{3}$ catalysts for dry reforming reaction. J. $\mathrm{CO}_{2}$ Util. 2017, 22, 124-134.

26. Jang, W.J.; Jung, Y.S.; Shim, J.O.; Roh, H.S.; Yoon, W.L. Preparation of a Ni-MgO- $\mathrm{Al}_{2} \mathrm{O}_{3}$ catalyst with high activity and resistance to potassium poisoning during direct internal reforming of methane in molten carbonate fuel cells. J. Power Sources 2018, 378, 597-602.

27. Ahmed, S.A.A.; Anis, H.F.; Ahmed, E.A. Effects of Selected Promoters on $\mathrm{Ni} / \mathrm{Y}_{-} \mathrm{Al}_{2} \mathrm{O}_{3} \mathrm{Catalyst}$ Performance in Methane Dry Reforming. Chinese J. Catal. 2011, 32, 1604-1609.

28. Zhu, F.; Zhang, H.; Yan, X.; Yan, J.; Ni, M.; Li, X.; Tu, X. Plasma-catalytic reforming of $\mathrm{CO}_{2}$-rich biogas over $\mathrm{Ni} / \gamma-\mathrm{Al}_{2} \mathrm{O}_{3}$ catalysts in a rotating gliding arc reactor. Fuel 2017, 199, 430-437.

29. Mei, D.; Ashford, B.; He, Y.-L.; Tu, X. Plasma-catalytic reforming of biogas over supported Ni catalysts in a dielectric barrier discharge reactor: effect of catalyst supports. Plasma Process. Polym. 2017, 14, 1600076.

30. Akbari, E.; Alavi, S.M.; Rezaei, M. Synthesis gas production over highly active and stable nanostructured $\mathrm{NiMgOAl}_{2} \mathrm{O}_{3}$ catalysts in dry reforming of methane: effects of Ni contents. Fuel 2017, 194, $171-179$.

31. Sudarsanam, P.; Hillary, B.; Deepa, D.K.; Amin, M.H.; Mallesham, B.; Reddy, B.M.; Bhargava, S.K. Highly efficient cerium dioxide nanocube-based catalysts for low temperature diesel soot oxidation: the cooperative effect of cerium- and cobalt-oxides. Catal. Sci. Technol. 2015, 5, 3496-3500. 
32. Pudukudy, M.; Yaakob, Z.; Akmal, Z.S. Direct decomposition of methane over SBA-15 supported Ni, Co and Fe based bimetallic catalysts. Appl. Surf. Sci. 2015, 330, 418-430.

33. Siew, K.W.; Lee, H.C.; Gimbun, J.; Chin, S.Y.; Khan, M.R.; Taufiq-Yap, Y.H.; Cheng, C.K. Syngas production from glycerol-dry (CO2) reforming over La-promoted $\mathrm{Ni} / \mathrm{Al}_{2} \mathrm{O}_{3}$ catalyst. Renew. Energy 2015, 74, 441-447.

34. Wang, W.; Wang, S.P.; Ma, X.B.; Gong, J.L. Recent advances in catalytic hydrogenation of carbon dioxide. Chem. Soc. Rev. 2011, 40, 3703-27.

35. Wu, J.; Fang, Y.; Wang, Y.; Zhang, D.K. Combined coal gasification and methane reforming for production of syngas in a fluidized-bed reactor. Energ. Fuel, 2005, 19, 512-516.

36. Lalit, S.G.; Guido, S.J.S.; Valero-Romero, M.J.; Mallada, R.; Santamaria, J.; Stankiewicz, A.I.; Stefanidis, G.D. Synthesis, characterization, and application of ruthenium-doped $\mathrm{SrTiO}_{3}$ perovskite catalysts for microwave-assisted methane dry reforming. Chem. Eng. Process.: Process Intensification 2018, 127, 178190. 